\title{
Depositional sequence analysis applied to Late Proterozoic Wilpena Group, Adelaide Geosyncline, South Australia
}

\author{
C. C. von der Borch, ${ }^{1}$ N. Christie-Blick ${ }^{2}$ and A. E. Grady 1 \\ ${ }^{1}$ Flinders University, Bedford Park, SA 5042, Australia. \\ ${ }^{2}$ Lamont-Doherty Geological Observatory of Columbia University, Palisades, New York, USA.
}

\begin{abstract}
The initial application of depositional sequence analysis to selected stratigraphic sections through outcropping Late Proterozoic strata of the Adelaide Geosyncline in South Australia has identified major depositional sequences within the several-kilometre-thick Wilpena Group. Sharp facies shifts in vertical stratigraphic sections are proposed as actual sequence boundaries which, provided they are the result of eustatic sea level variations, may be key elements for future attempts at inter-regional chronostratigraphic correlation.
\end{abstract}

Two major sequence boundaries are identified, one at the base of the Nuccaleena Formation (boundary A) and a second at the top of the Brachina Subgroup (boundary B). These are attributed to significant basinward shifts in coastal onlap resulting in subaerial exposure and at least localized erosion, followed in each case by establishment of relatively deepwater environments. A somewhat different boundary (boundary $\mathrm{C}$ ) is associated with an interval of diagenetic dolostone interbeds and is interpreted either as a downlap surface within a sequence, or as a combined deepwater sequence boundary and downlap surface. It may have developed during an episode of reduced sediment input in response to a period of maximum transgression. Alternatively it may represent a hiatus at the termination of a depositional sequence, prior to subsequent downlap or onlap of the succeeding sequence.

Boundary $\mathrm{C}$ lies a few metres below the stratigraphic level from which kilometre-deep canyons have incised underlying sequences. These canyons, which are infilled by a complex succession of carbonate breccias, conglomerates, sandstone and mudstone, may have been eroded in a submarine setting by turbidity currents. Such a model requires a significant increase in rate of eustatic sea level fall or a decrease in the rate of tectonic subsidence, in order to move the locus of coastal onlap to the vicinity of the shelf edge. If the cause was eustatic, evidence for it should be found at an equivalent sequence boundary in Late Proterozoic basins remote from the Adelaide Geosyncline. Alternatively, the canyons may have been eroded in a subaerial setting and infilled by coastal sediments during an ensuing period of relative sea level rise. In this model a considerably greater drop in relative sea level is required, most likely related to localized tectonic uplift.

Key words: Adelaide Geosyncline, depositional sequence analysis, stratigraphy, Wilpena Group.

\section{INTRODUCTION}

Most correlation in Proterozoic strata has conventionally been lithostratigraphic rather than chronostratigraphic in nature because of the obvious lack of biostratigraphic resolution, the small number of reliable radiometric ages and limited palaeomagnetic data. Gross stratigraphic subdivisions of the Proterozoic have been based on obvious angular unconformities but, with the exception of such prominent breaks, Proterozoic sedimentary rocks have conventionally been viewed as conformable. In most cases it has not been possible to detect lesser hiatuses in concordant strata, even where their presence has been suspected from radiometric dating.
Such assumed conformity and continuity of sedimentation is not borne out by detailed sedimentological and stratigraphic observations, especially in younger rocks for which better age resolution is possible. Although strata commonly appear to be concordant when viewed from a distance, at all scales they actually consist of hierarchically arranged layers varying from millimetres to hundreds of metres in thickness. Each layer is bounded by stratal surfaces which represent discontinuities in sedimentation at time scales ranging from less than $10^{-7}$ to more than $10^{9}$ years (Campbell 1967; Dott 1983). On a scale of tens to hundreds of metres, many sedimentary successions are composed of 'depositional sequences' (Fig. 1), essentially hierarchical 

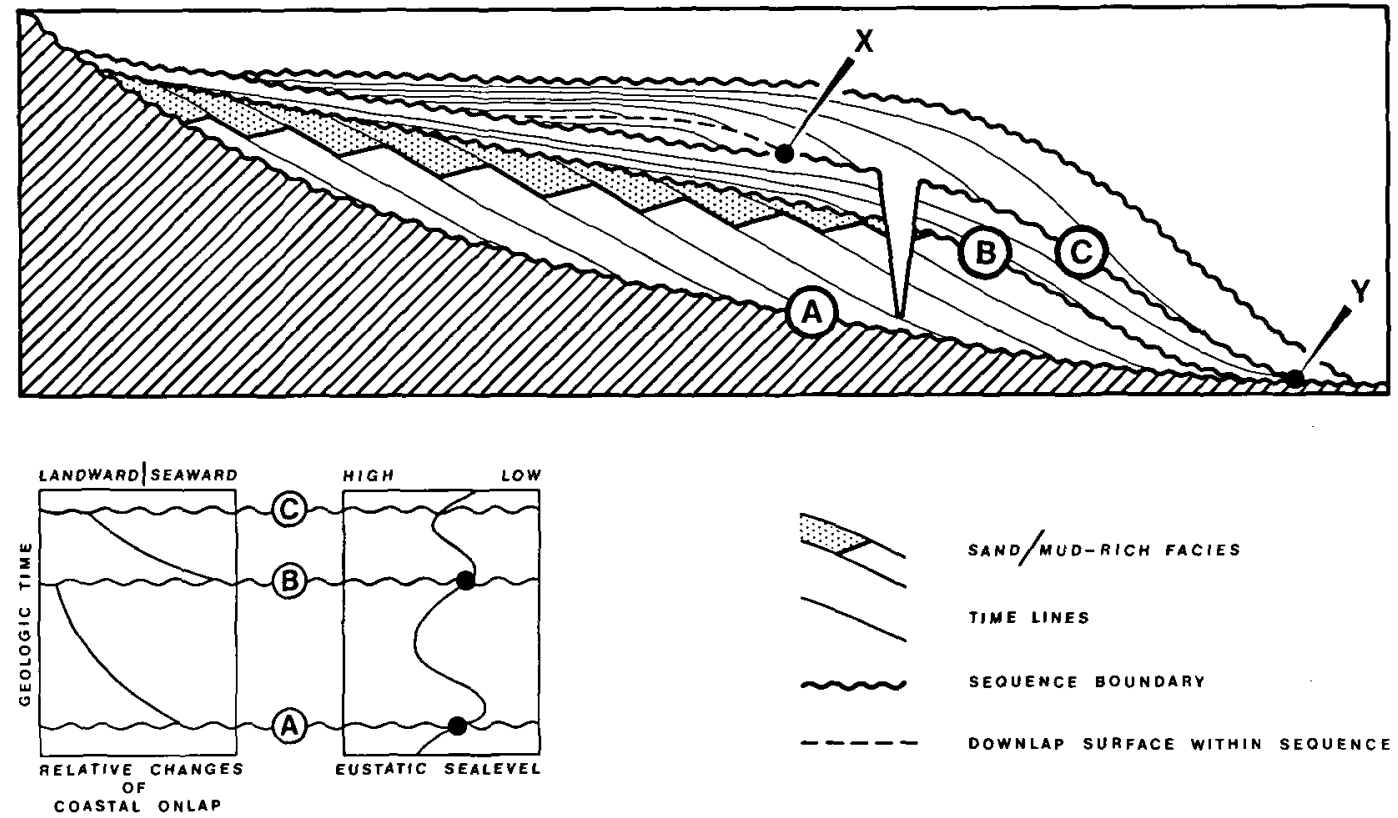

Fig. 1 Diagrammatic illustration of three hypothetical depositional sequences, separated by sequence boundaries A, B and C. Eustatic sea level and relative coastal onlap curves (after Vail et al 1984) illustrate simplest of several possible causes of sequence boundary formation. Note downlap surface, and region $\mathrm{X}-\mathrm{Y}$ which is a combined downlap surface and sequence boundary; note also erosional incision (canyon) which relates to events associated with sequence boundary $C$. The degree of vertical exaggeration is extreme; e.g. for typical second-order sequences, vertical distance between $A$ and $B$ could be in kilometres, whereas the lateral extent of the sequence could measure tens or hundreds of kilometres.

packages of genetically related lithofacies, bounded by regional unconformities or their correlative conformities (Vail et al 1977, 1984). In Mesozoic and younger deposits from which most seismic reflection data are available, these surfaces are easily recognized on seismic profiles. Mitchum et al (1977) and Vail et al (1977) have termed the surfaces sequence boundaries, and they have been utilized to develop timestratigraphy in sedimentary basins subject to exploration for petroleum (the seismic stratigraphic approach). Although sequence boundaries usually represent hiatuses of variable duration, they have chronostratigraphic significance because with few exceptions it is common for strata above an unconformity to be everywhere younger than strata below it.

The fundamental premise of this paper is that as in Phanerozoic successions, Proterozoic rocks should consist of hierarchical depositional sequences bounded by sequence boundaries, broadly comparable to the patterns shown by the simplified model in Fig. 1. The identification of Proterozoic sequence boundaries in outcrop should improve relative time-stratigraphy and upgrade depositional models. Sequence boundaries commonly correspond with abrupt facies discontinuities in stratigraphic sections, and models which assume continuous sedimentation across such boundaries may be incorrect. The sequence analysis technique utilized in this paper has successfully been applied to the $1.89 \mathrm{Ga}$ Rocknest Formation in northwestern Canada by Grotzinger (1986).

Here we present initial results of sequence analysis applied to the lower Wilpena Group of the Late Proterozoic Adelaide Geosyncline (von der Borch 1980; Rutland et al 1981) in the northern Flinders Ranges of South Australia (Fig. 2). We set out to characterize some of the major sequence boundaries as they appear in outcrop and to document their sedimentology, 
but postpone discussion of regional variations of the boundaries and detailing of higher-order sequences. The Wilpena Group has been selected for analysis because the approximately equivalent stratigraphic interval, bracketed between the Precambrian glaciations and the Precambrian-Cambrian boundary, can readily be identified on other continents and therefore critically compared. The style of sedimentation and major cyclicity within this interval is remarkably similar throughout Australia, and between Australia and North America, raising the so far untested possibility of a eustatic control of base level during sedimentation of some of the depositional sequences. This opens the further possibility of inter-regional chronostratigraphic correlation, and is one of the main reasons for initiating the present analysis of sequence boundaries. An important brief of a related ongoing study on the Late Proterozoic and Early Cambrian Brigham Group, Utah, USA (Christie-Blick \& Levy 1985; Christie-Blick \& von der Borch 1985), is to test this premise. The Wilpena Group also hosts kilometre-deep erosional canyons (von der Borch et al 1982, 1985) which, although their origin is debatable, may be analogous to major incisions associated with prominent sequence boundaries beneath many present-day passive margins (Vail et al 1977).

\section{SEQUENCES, SEQUENCE BOUNDARIES AND DOWNLAP SURFACES IN OUTCROP}

\section{Sequences}

A stratigraphic log across an individual depositional sequence may show a variety of stratigraphic patterns, depending upon the section location with respect to basin geometry. A typical example for siliciclastic sediments could begin with shallow-water facies at the base (onlap) or might exhibit apparently rapid appearance of what may be interpreted as relatively deepwater sediments superimposed at a sharp boundary over shallow-water or subaerial sediments of the underlying sequence. In the case of a second- or third-order sequence, relatively deepwater facies may then persist upsection for an interval of tens to hundreds of metres, at which point sedimentological evidence of shallowing conditions may be encountered. Ultimately such a sequence may be capped by regressive sediments in the form of hummocky cross-stratified sandstones overlain by mature, nearshore sandstones. These either may persist up to the overlying sequence boundary, or could pass upsection to coastal plain sediments beneath an overlying sequence boundary.

\section{Sequence boundaries}

Sequence boundaries can be recognized in three ways: (1) from the termination of layering (Fig. 1) by onlap, downlap, toplap and erosional truncation (Vail et al 1977, 1984); (2) by biostratigraphy; and (3) from facies discontinuities. The first method is the one used in seismic stratigraphy, but regional stratal terminations are subtle and difficult to observe in limited outcrop (Bjorlykke 1982). They can be detected in regional mapping, especially where the structure is relatively simple, such as in the Triassic and Jurassic strata of the Colorado Plateau (Pipiringos \& O'Sullivan 1978), and in his studies of turbidites in the Eocene Hecho Group, in the south-central Pyrenees of Northern Spain, Mutti (1985) has successfully mapped sequence boundaries on aerial photographs. Biostratigraphy is one of the oldest methods of identifying interregional unconformities (Sloss 1963), but as stated above, is applicable only in a very broad way to Proterozoic rocks. The interpretation of most Proterozoic sequence boundaries, therefore, must be based primarily on facies discontinuities, and this is the technique employed in this paper.

Facies discontinuities of this type, viewed in outcrop, vary from obvious to cryptic, depending upon several factors. These include the degree of shift of coastal onlap during sequence boundary formation, presence or absence of erosional truncation of the underlying sequence, rates of relative sea level rise following sequence boundary development, and the actual location of the outcrop section with respect to basin palaeogeography. At one end of the spectrum, therefore, an abrupt facies discontinuity may be observed across such a boundary, commonly between nearshore marine to subaerial facies of the underlying sequence and what may be construed as relatively deepwater, low energy shales. In a more complex situation, small scale cyclicity 

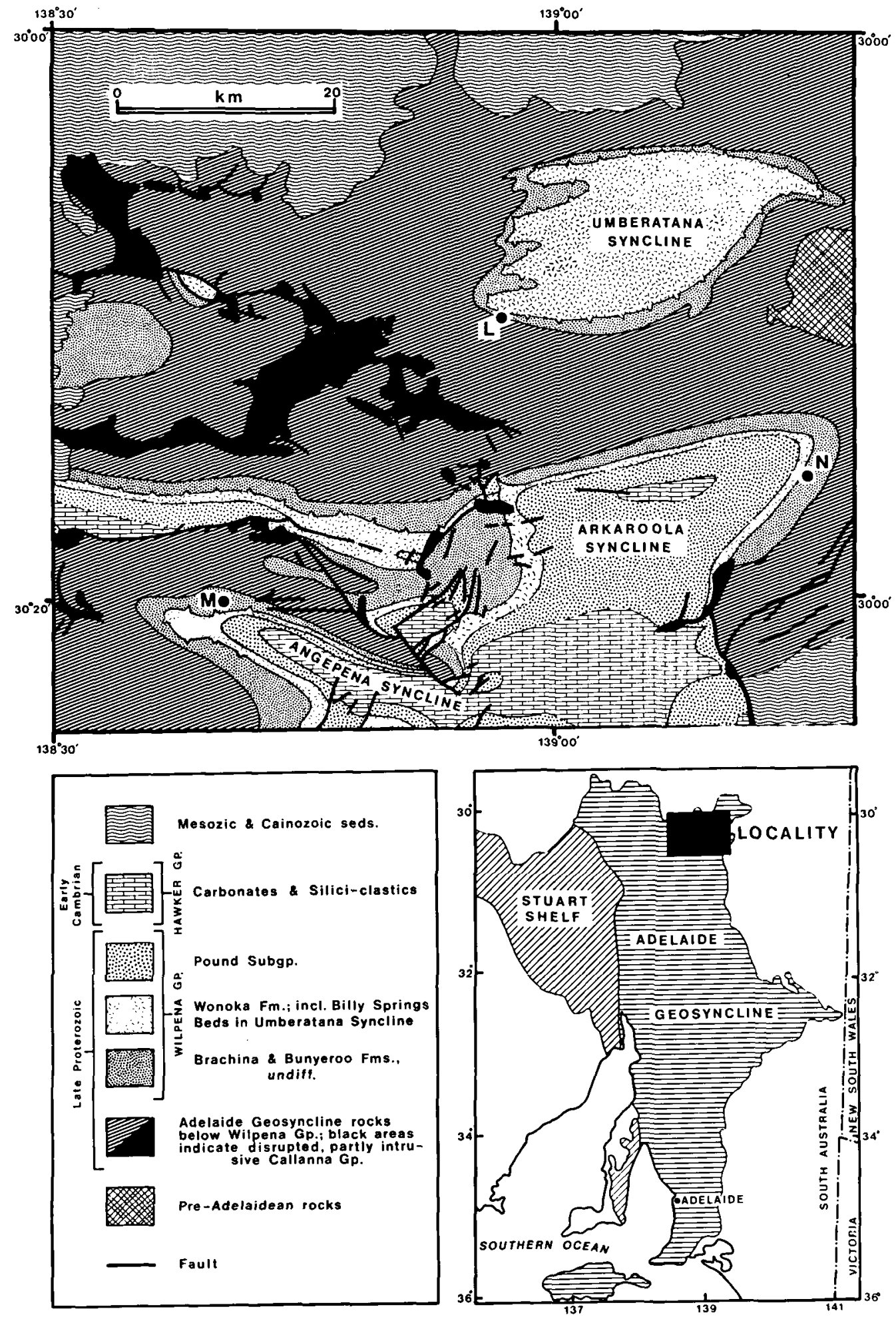
may be observed within an interval above such a boundary, ultimately grading upsection to more uniform deeper water facies. If, on the other hand, the transition represents a 'deepwater' sequence boundary, careful stratigraphic logging and facies analysis may be required, and it may even be necessary to map such a boundary for a considerable distance along strike in order to correlate it with confidence with a more obvious transition elsewhere.

\section{Downlap surfaces}

A downlap surface (Fig. 1) is a surface within a sequence which commonly corresponds with the time of maximum transgression (Vail et al 1984). Such a surface is a marine hiatus, and may be associated in outcrop or drill core with a thin but continuous zone of lithified beds (hardgrounds) and concentrations of rare authigenic components such as glauconite or phosphorite.

\section{SEQUENCE ANALYSIS OF WILPENA GROUP}

\section{General description}

The generalized stratigraphy of the Wilpena Group in the northern Flinders Ranges is illustrated in Fig. 3. Two first-order coarseningupward sequences have been proposed by Plummer (1978a) as constituting most of the Group, the lower being the Brachina Subgroup (Nuccaleena and Brachina Formations and ABC Range Quartzite) and the upper extending from the base of the Bunyeroo Formation to the top of the Bonney Sandstone. In the present study these first-order sequences have been partly subdivided into second- or third-order sequences.

The Brachina Subgroup is a kilometre-thick shallowing-upward unit with a thin, persistent dolostone, the Nuccaleena Formation at its base. This grades upsection to olive-drab mudstone

Fig. 2 Locality map of the Late Proterozoic Adelaide Geosyncline and Stuart Shelf (lower right) and details of northern Flinders Ranges geology. Adapted from 1:600 000 geological map compiled by Preiss (1983). Specific localities for boundaries A, B and C discussed in text are lettered $L, M$ and $N$, respectively (cf. Figs 3, 4). Note major canyons infilled by sediments of Wonoka Formation near $\mathrm{L}$ and $\mathrm{M}$. and immature sandstone, which in turn give way to interbedded mudstone and hummocky crossstratified sandstone, slumped mudstone and ultimately to a mature nearshore-facies sandrich unit, the $A B C$ Range Quartzite.

Overlying the $A B C$ Range Quartzite with sharp contact is the Bunyeroo Formation, dominantly a monotonous grey-red to blue-grey laminated to massive mudstone, approximately $500 \mathrm{~m}$ thick. The Bunyeroo Formation typically has basal sand-rich horizons, and is abruptly capped by a thin (1-2 $\mathrm{m}$ ) zone of concretionary and intraclastic dolostones, the uppermost of which has been selected by Gostin and Jenkins (1983) to define the base of the Wonoka Formation. Several hundred metres of mixed siliciclastic and carbonate sediments comprising the Wonoka Formation overlie the Bunyeroo Formation. The Wonoka Formation hosts at least two second- or third-order sequences, which are currently being analysed (di Bona \& von der Borch 1985). Haines (1986a, b), from a regional study of the formation in the central and southern Flinders Ranges, emphasizes the significance of hummocky cross-stratification in calcareous sandstones throughout much of middle to upper Wonoka Formation.

A major interval of sandstone, the Pound Subgroup, overlies the Wonoka Formation, attaining a thickness in excess of $3 \mathrm{~km}$ in the Arkaroola Syncline (Figs 2,3). The interval is composed of the Bonney Sandstone and overlying Rawnsley Quartzite. The cyclical Bonney Sandstone is characterized by feldspathic sandstone and interbedded red-brown mudstone representing a complex of subtidal, intertidal and fluvial environments. The overlying Rawnsley Quartzite contains only minor mudstone interbeds. It embraces at least two third- or fourth-order depositional sequences (not shown on Fig. 3), which locally host the Ediacara Fauna (Gehling 1983; Jenkins et al 1983).

Major canyon-like features of the Wilpena Group have been eroded down in excess of $1 \mathrm{~km}$ into the Bunyeroo Formation and Brachina Subgroup from a zone within the lower Wonoka Formation (Fig. 3). One of these, 'Patsy Springs Canyon' (von der Borch et al 1982), is exposed in the axial part of the Angepena Syncline; a portion of a canyon, interpreted as meandering, crops out as a series of west-trending incisions along the western margin of the Arkaroola Syncline (Fig. 


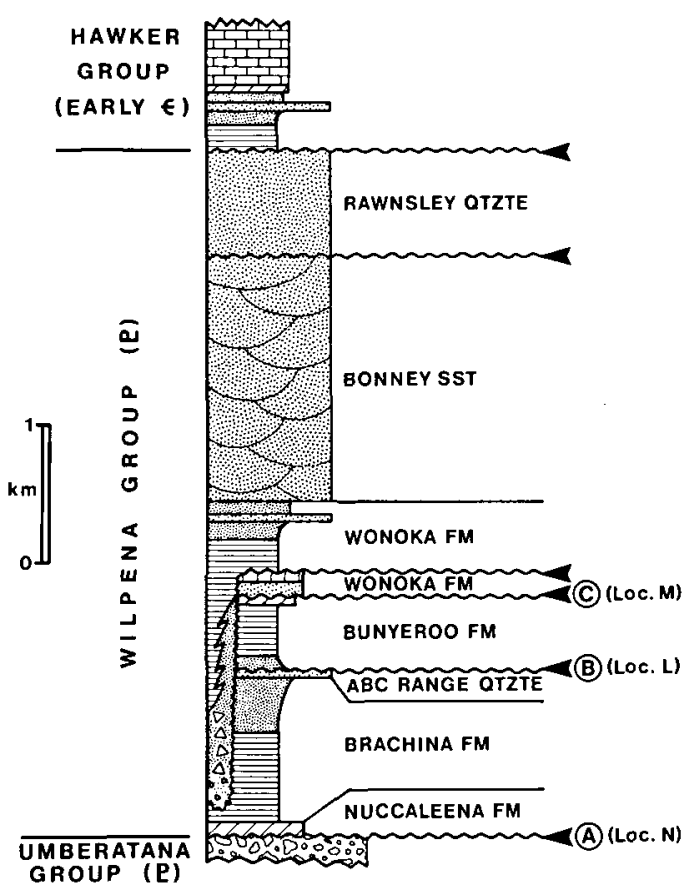

Fig. 3 Diagrammatic stratigraphy (not to exact scale) of Wilpena Group in northern Flinders Ranges. A, B and C refer to major boundaries discussed in text, at localities $L, M$ and N, respectively (cf. Figs 2 and 4); three additional major sequence boundaries currently under study are indicated by unlettered arrows. Note stratigraphic relationships of canyons, which are eroded down from a cryptic sequence boundary within lower Wonoka Formation slightly above boundary C. Brachina Subgroup (see text) incorporates Nuccaleena and Brachina Formations and $\mathrm{ABC}$ Range Quartzite.

2). These canyons are infilled by quartzite-pebble conglomerate, carbonate breccia, quartzose sandstone and calcarenite, constituting a distinctive facies of the lower Wonoka Formation. This is overlain by a siliciclastic mudstone, quartzose sandstone, calcarenite, calcareous mudstone and carbonate breccia.

\section{Major sequence boundaries, lower Wilpena Group}

Stratigraphic and sedimentological aspects of major sequence boundaries and a possible downlap surface within the lower Wilpena Group are illustrated in Figs 3 and 4 (boundaries A, B and C) and are detailed below. Geographic locations of the three sections containing boundaries $A, B$ and $C$ are shown as $L, M$ and $N$, respectively, on Fig. 2 . We emphasize that the boundaries we identify have previously been recognized as formation, member or group boundaries, for the simple reason that sequence boundaries commonly separate sediments of distinctly contrasting facies. However, diachronous facies boundaries (e.g. base of hypothetical sandstone unit below sequence boundary B, Fig. 1) are not sequence boundaries, despite the fact that they may be designated as formation boundaries. In this context, the base of the ABC Range Quartzite is not identified as a sequence boundary in Figs 3 and 4, although it is a formal formation boundary.

\section{SEquence Boundary A}

\section{Description}

Sequence boundary A (Fig. 4) defines the base of the Wilpena Group. Variations on the theme described below have been noted in central and southern regions of the Adelaide Geosyncline, but the section (locality L, Fig. 2) is representative of the area selected for initial study and displays key elements of this particular. boundary. 


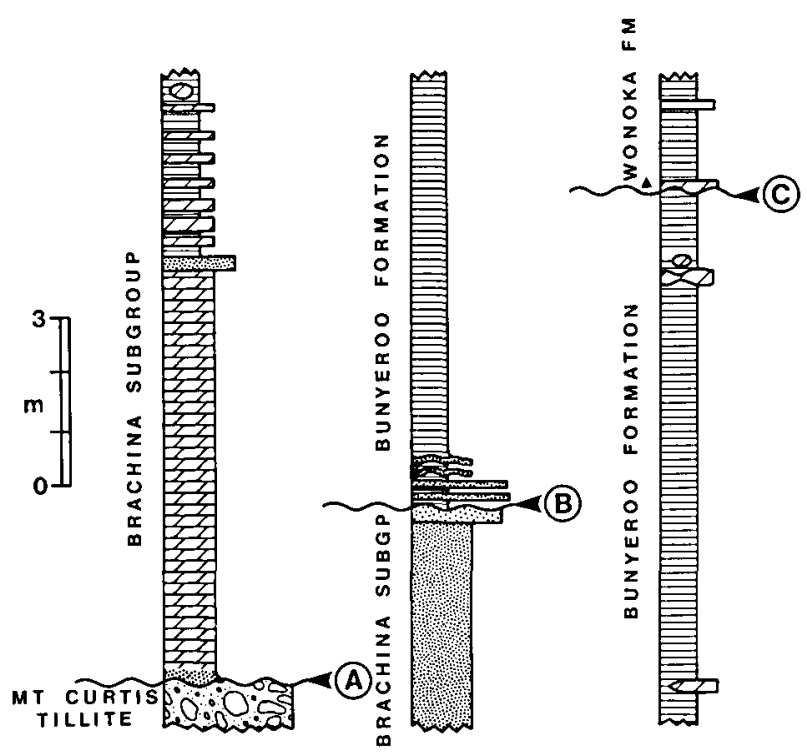

Fig. 4 Details of stratigraphy across the three selected boundaries, A, B and C. The dolomitic unit above sequence boundary $\mathrm{A}$ is the Nuccaleena Formation, which grades upsection via interbedded dolostones, dolomitic concretions and shale into the dominantly shaly section composing much of the lower Brachina Subgroup. The sandy unit immediately below sequence boundary B is the ABC Range Quartzite, which 'caps' the Brachina Subgroup.

The Mount Curtis Tillite, at the top of the underlying Umberatana Group, is a severalmetre-thick polymict pebbly sandstone of possible glacial-marine origin. It is composed of a variety of poorly sorted basement-derived clasts of up to boulder size, in a sandy matrix. Overlying the Mount Curtis Tillite, or locally a trough cross-bedded feldspathic sandstone (Balparana Sandstone), with a sharp contact, is a several-metre-thick dolostone, the Nuccaleena Formation. A distinct disconformity is present locally between the base of the Nuccaleena Formation and the underlying Balparana Sandstone or Mount Curtis Tillite. The basal few centimetres of the dolostone at locality $\mathrm{L}$, overlying the Mount Curtis'Tillite, contain reworked sand and gravel probably derived from the underlying pebbly sandstone. The lowermost few metres of the Nuccaleena Formation consist of a flaggy pink dolomicrite which ranges in texture from massive to diffusely banded and possibly algal laminated. In nearby areas stromatolites, intraclast breccias and teepee structures have been reported (Plummer 1978b; Williams 1979). Towards its top the Nuccaleena Formation grades into grey-green mudstone via interbedded thin dolomite layers and concretions and siliciclastic mudstone. Interbeds of siliciclastic mudstones then increase in thickness at the expense of layered and nodular dolostones of the upper Nuccaleena Formation. Above this level the dominantly siliciclastic Brachina Subgroup begins what normally is a kilometre-thick upwards-coarsening succession. At locality L, subsequent canyon erosion related to Wonoka Formation deposition has removed much of the Subgroup.

\section{Interpretation}

The lower portion of the Nuccaleena Formation in the study area is interpreted as peritidal in origin. Dolostones of this type typically form in sea-marginal saline and alkaline ephemeral lakes and associated sabkhas. These environments can develop approximately at sea level immediately landward of the shoreline, where continental groundwaters become buoyed upwards over the more dense marine porewaters. Chemical evolution of evaporitically modified groundwaters and admixed seawater provides appropriate conditions for genesis of 'penecontemporaneous' microcrystalline dolostones and associated supratidal dolomitic crusts and teepees, a 
modern example being the Coorong region of South Australia (von der Borch \& Lock 1979). The Nuccaleena Formation is most likely transgressive in origin and consequently a diachronous unit. The upper portion of the formation may have been partly derived by reworking of the lower portion, with transgressive mudstone of the overlying lower Brachina Subgroup ultimately overwhelming the peritidal carbonates to dominate the sequence.

The mappable boundary separating the Mount Curtis Tillite and the Nuccaleena Formation (Figs 3 and 4) was previously defined as a group boundary (Thompson et al 1964). The location of the lowermost sequence boundary defined in this paper is placed at this distinct facies break.

\section{SEquence Boundary B}

\section{Description}

The stratigraphic section is situated in a region (locality M, Fig. 2) where a thick succession of green argillaceous sandstone and siltstone of the Brachina Subgroup is overlain by several centimetres of a cross-bedded quartzite, which may correlate to the south with the $A B C$ Range Quartzite. The Bunyeroo Formation lies with sharp contact over this thin quartzite, and has at its immediate base a $20-30 \mathrm{~cm}$ thick cupriferous unit composed of trough cross-bedded and rippled coarse grained sandstone lenses, and interbedded millimetre- to centimetre-thick red mudstone. Towards the top of this thin basal unit the 'sands decrease in grain size and are associated with flaser and wavy bedding. Several centimetres farther upsection the sand content diminishes and a monotonous massive to finely laminated red-brown to green silicic mudstone, typical of the bulk of the Bunyeroo Formation, dominates the sequence. The basal contact of the Bunyeroo Formation is likewise sharp in all areas of the Flinders Ranges, either directly over welldeveloped ABC Range Quartzite or, where this is absent, argillaceous sandstones of the uppermost Brachina Subgroup. In the western Bayley Range area (Copley 1:250 000 geological sheet; Coats 1973) typical Bunyeroo Formation mudstone overlies several metres of interbedded sandstone and reddish-brown mudstone with intercalated dolomitic quartzite-pebble breccias, calcite pseudomorphs after discoidal gypsum, and carbonate clast breccias. These are assigned to the lowermost Bunyeroo Formation and overlie mature sandstone of the $\mathrm{ABC}$ Range Quartzite.

\section{Interpretation}

The ABC Range Quartzite is interpreted as the regressive nearshore facies 'cap' of the lowermost major depositional sequence of the Wilpena Group. Breccias of obviously pre-lithified quartzite pebbles, locally intercalated within the basal Bunyeroo Formation, imply that induration of the $A B C$ Range Quartzite was well advanced prior to Bunyeroo Formation deposition. The basal portion of the Bunyeroo Formation is best interpreted as a transgressive nearshore deposit, possibly of tidal origin and locally with evaporitic affinities. The sharp contact between the ABC Range Quartzite and basal Bunyeroo Formation is interpreted as a sequence boundary (boundary B) at the base of a second major depositional sequence within the Wilpena Group.

\section{SEQUENCE BOUNDARY OR DOWNLAP SURFACE C}

\section{Description}

A sharp-based and locally channelled intraclastic dolostone, about $15 \mathrm{~cm}$ thick, occurs at locality $\mathrm{N}$ (Fig. 2), at the stratigraphic level of boundary $\mathrm{C}$ (Figs 3, 4). The dolostone separates metallic-grey laminated siliciclastic mudstone of the redefined (Jenkins \& Gostin 1983) upper Bunyeroo Formation from overlying siliciclastic mudstone and flaggy calcarenite of the Wonoka Formation. Locally this dolostone exhibits several thin (about $5 \mathrm{~cm}$ ) graded beds of mixed carbonate and siliciclastic sandstone and mudstone with carbonate intraclasts. Immediately below the intraclastic dolostone, the upper Bunyeroo Formation contains two thin (about $5-10 \mathrm{~cm}$ ) concretionary beds of diagenetic dolomite, similar to the thin interbeds of dolomite present at the same stratigraphic level in the Bunyeroo Gorge area (Haines 1986a). Dolostones of this type are widespread at this stratigraphic level throughout the central and northern Adelaide Geosyncline. In the region of section $C$, the several-hundred-metre-thick Bunyeroo Formation below these dolostones is composed entirely of monotonously laminated mudstone. In the vicinity of St Ronan's Well (Copley 
1:250 000 geological sheet; Coats 1973), the uppermost few metres of the Bunyeroo Formation host several thin $(10-20 \mathrm{~mm})$ sandstones and a thin intraclastic calcareous sandstone, interbedded with grey-red mudstone. This interval is overlain abruptly by a succession of sharp-based siliciclastic sandstone with flute casts and interbedded grey-red mudstone. Hummocky crossstratification is present within many of the sandstone beds. This unit is typical of the lower Wonoka Formation in the central and southern Flinders Ranges and correlates with Wonoka Formation Unit 2 of Haines (1986a). Gostin and Jenkins (1983) suggested that sandstones, now designated as belonging to Unit 2 and interpreted as turbidites, are genetically related to the process which caused erosion of the canyons. Dolostones of Wonoka Formation Unit 1 of Haines (1986a) are not represented at this locality.

The uppermost level of incision of the canyons terminates at an interval which lies several metres above boundary C (Fig. 3). At Patsy Springs Canyon (Fig. 2, near locality $M$ ), the canyon shoulder lies a few metres above a thin dolostone, which most likely correlates with the intraclastic dolostone defining the base of the Wonoka Formation. The interval between this intraclastic dolostone and the canyon shoulder is composed of 2-3 $\mathrm{m}$ of interbedded hummocky cross-stratified sandstone and mudstone of the lower Wonoka Formation, which are correlated in a lithostratigraphic sense with Unit 2 of Haines (1986a). These sediments are overlain by a second thin dolostone and a metre-thick pink, flaggy calcarenite, which can be traced into a pink calcarenite and carbonate breccia mantling the canyon wall.

\section{Interpretation}

The monotonous fine grained and commonly finely laminated nature of Bunyeroo Formation mudstones implies relatively quiet deepwater conditions. Lack of associated sandy material, except locally near the base and top, may imply a bypass-slope setting. The thin sandy interbeds in some localities near the top of the formation suggest the beginning of a subtle upwardsshoaling event which, in the region of accessible outcrop, clearly did not progress to subaerial conditions.

Concretionary dolostones at the top of the Bunyeroo Formation are interpreted as having formed during diagenesis, analogous to dolomite formation in organic-rich continental-margin sediments described by Baker and Burns (1985). Dolomites of this type can form where organic carbon content exceeds $0.5 \mathrm{wt} \%$ and where sedimentation rates are relatively low. If such a model applies to the uppermost Bunyeroo Formation, then a condensed interval is implied for this portion of the section, perhaps related to a downlap surface or a combined sequence boundary and downlap surface (e.g. X-Y; Fig. 1). A surface of this nature would have experienced a prolonged period of exposure on the seafloor in relatively deep water, prior to burial. Subsequent burial may have been caused by the downlapping or onlapping of succeeding units on to the sequence boundary. The intraclastic dolostones (Wonoka Formation Unit 1 of Haines 1986a) which overlie this boundary most likely represent lag deposits, developed on the seafloor during a period of low sediment input by the erosion and winnowing of the concretionary dolostones. The overlying sandstone (Wonoka Formation Unit 2 of Haines 1986a), commonly with hummocky cross-stratification, is of uncertain derivation. It may imply lower shoreface sedimentation under the influence of stormdeveloped oscillations (Walker 1984), or may represent deepwater deposition, imprinted by deepwater hummocky cross-stratification of the type described by Prave (1985). Further work is obviously required at this critical stratigraphic level, particularly in view of the major canyon erosion event that appears to coincide with or immediately post-date deposition of these sandstones.

\section{DISCUSSION AND CONCLUSIONS}

Late Proterozoic strata at the approximate stratigraphic level of the Wilpena Group exhibit remarkable similarities over a broad region. Within the Australian continent, for example, Preiss et al (1978), Coats and Preiss (1980) and Preiss and Forbes (1981) demonstrate similarities of lithology and sedimentary style within several major cycles between the Kimberley Ranges of northwestern Australia, the Amadeus Basin of central Australia, and the Adelaide Geosyncline. These cycles, in the context of this paper, would be described as depositional sequences. Although further research is required, some of the sequence boundaries between the 
large-scale (first-, second- and third-order) sequences may be correlative in a chronostratigraphic sense. The present authors also note striking similarities between several sequences in approximately time-equivalent strata of the North American Cordillera and those of the Adelaide Geosyncline, and Young (1981) hints that Proterozoic rocks of the western Pacific continents may represent a rifted portion of the North American Cordillera. It is therefore possible, although by no means proven, that eustatically-driven base level control may have played a major role in producing some of these similarities.

In order to seek underlying reasons for the above observations, a fundamental step is precisely to identify and characterize the major sequence boundaries - the purpose of this paper. The next step, briefly covered in this discussion, is to seek evidence of what actually triggered sequence boundary development. This most likely was due to significant lowerings of relative sea level. The important question is whether localized tectonism was responsible for the observed relative sea level changes, or whether eustatic sea level variations, induced by changes in the geometry of the ocean basins or the volume of continental ice, may have been responsible.

\section{Evidence of significant seaward migrations of coastal onlap}

Sequence boundary A (Fig. 4) is associated with a sharp facies break between the Mount Curtis Tillite and Nuccaleena Formation. While it is not yet possible to propose a specific depositional environment for pebbly and bouldery sandstones of the Mount Curtis Tillite, this is locally overlain by a texturally mature sandstone unit, the Balparana Sandstone, which has possible fluvial affinities and which clearly was truncated and locally removed by erosion prior to Nuccaleena Formation deposition. The abrupt lithological change to the interpreted 'supratidal' dolostone, which grades upsection to mudstone and fine grained sandstone, implies coastal onlap on to the sequence boundary during transgression, followed by overall deepening.

The Nuccaleena Formation is strikingly similar, both in lithology and stratigraphic position, to other 'cap dolomites' which overlie Late Proterozoic glaciogene successions in the Kimberley Ranges (Williams 1979; Coats \&
Preiss 1980) and Amadeus Basin (Preiss et al 1978). The widespread presence of such thin (several metres thick) dolostone units, at the base of a clearly transgressive succession, implies transgression of a broad, low gradient coastal plain, following emergence and erosion. The close association of such dolostones with underlying glaciogene strata argues strongly for glacio-eustatic control, possibly due to Late Proterozoic deglaciation, as previously suggested by Preiss and Forbes (1981). Although further verification is required, it is tempting to propose that sequence boundary $A$ in the Adelaide Geosyncline is indeed related to a eustatic event, with the corollary that boundary $A$ is of global chronostratigraphic significance.

Sequence boundary B (Fig. 4) is taken at a sharp contact between what is interpreted as a nearshore marine sandstone unit (ABC Range Quartzite) and thin overlying sandstone and interbedded mudstone of the basal Bunyeroo Formation. The ABC Range Quartzite here is only centimetres in thickness, compared with several hundred metres farther south. Although equivocal, it is possible that subaerial erosion has removed much of the $\mathrm{ABC}$ Range Quartzite at locality $\mathrm{M}$ (Fig. 2). However, the thinning is more likely to be depositional and to relate to lateral facies changes. Basal sediments if the Bunyeroo Formation which overlie boundary B demonstrate a distinct upwards-fining trend, and in a nearby locality contain rare calcite pseudomorphs after discoidal gypsum, suggesting at least localized subaerial exposure. The evidence again points to a significant seaward migration of coastal onlap associated with boundary B, followed by onlap on to the sequence boundary of basal Bunyeroo Formation and subsequent development of relatively deepwater mudstone. Sequence boundary B exhibits a similar style throughout widespread areas of the Adelaide Geosyncline. Such a lack of regional variation is difficult to reconcile with localized changes in tectonism or sedimentation rates. It is proposed that a eustatic sea level control best accounts for the evidence.

Boundary C (Fig. 4) is interpreted either as a downlap surface within a sequence, or as a combined sequence boundary and downlap surface. Whatever its character in seismic stratigraphic terms, it is considered to represent a relatively 'deepwater' boundary, at least in the vicinity of locality N (Fig. 2) and possibly over a large part of the central and northern Adelaide Geosyncline. 
If this interpretation is correct, it contrasts with the inferred subaerial nature of boundaries $A$ and $B$ at localities $L$ and $M$. Boundary $C$ is of added interest because it lies just below the stratigraphic level from which the large canyons were incised into underlying sequences. Because of the obvious significance of the canyon-forming process in the context of global or local base level changes, some aspects of the canyons are discussed below.

\section{Canyon erosion}

Large scale erosional incisions or canyons, with vertical dimensions measured in hundreds of metres to in excess of one kilometre, within the Wonoka Formation (von der Borch et al 1982, 1985) have been described as submarine canyons, with the inference that much of their erosion and infilling was submarine in origin and related to turbidity current activity on basin slopes. Another possibility is that erosion of these features could in part have been subaerial (Eickhoff et al 1986). Infilling sediments may even be of estuarine origin. Each interpretation has important implications for possible eustatic sea level changes, which in turn have a bearing on global correlation of Late Proterozoic depositional sequences. A key element in the debate relates to the interpreted environments of deposition of the canyon-filling sediments. The lack of faunal remains makes this a difficult task, with often equivocal sedimentary structures providing the only available data. In addition, there is a lack of reliable facies models both for estuaries and for submarine canyons.

Canyon-filling sediments of the Wonoka Formation constitute an upwards-fining succession. Basal sediments are typically breccias and conglomerates, with clasts composed of diverse carbonates and quartzites as well as obvious canyon-wall lithologies derived from the Brachina Subgroup, Bunyeroo Formation and Unit 2 (Haines 1986a) of the Wonoka Formation. Interbedded with and overlying basal breccias are mixed carbonate and siliciclastic sandstone and interbedded mudstone. Sandstone beds, which vary in thickness from centimetres to in excess of one metre, often display sharp bases, well-defined flute casts and abundant climbing ripples. Some sandstones display features which could be ascribed to a turbidity current origin, typically $\mathrm{Tbc}$, Tbcd and more rarely Tabcd of the Bouma sequence.
However, many throughout the canyon-fill are characterized by hummocky cross-stratification, which is normally interpreted as having developed in lower shoreface environments (see Walker 1984), but which has also been described in deepwater sediments (Prave 1985).

The canyons may have been excavated in a submarine setting, either by turbidity currents, mass-movements, or a combination of these processes. In this model, a significantly seaward shift in coastal onlap to the vicinity of the shelf edge is required prior to canyon excavation in order to permit canyon-cutting clastics to be transported to a slope environment. The vertical drop in coastal onlap in this model needs to be of the order of $200 \mathrm{~m}$. According to field stratigraphic relationships, the stratigraphic position of this event coincides with a cryptic sequence boundary situated several metres above Unit 2 (Haines 1986a) of the Wonoka Formation.

Another possibility, also related to a submarine erosion model, places the canyontriggering seaward shift in coastal onlap at a lower stratigraphic level, possibly coinciding with sequence boundary $B$. In this model a major sequence (Bunyeroo Formation), and possibly lesser sequences within lowermost. Wonoka Formation), were deposited on the shelf and slope around shoulders of previously incised canyons, similar to the situation described for a Quaternary canyon offshore from New Guinea (von der Borch 1969). Mass movements during submarine cutting and subsequent infilling of the canyons could then have caused widening and lateral wasting of the Bunyeroo Formation and overlying sequences which draped canyon interfluves, thereby accounting for clasts derived from these units in canyon-wall breccias. Canyons could subsequently have become infilled by marine onlap prior to deposition of middle to upper Wonoka Formation sediments.

An alternative model relates to subaerial erosion and subsequent infilling by shallow marine sediments during coastal onlap. In its simplest form, this requires a relative base level fall of the same order of magnitude as that of the actual canyon depth - about $1 \mathrm{~km}$. Such a fall could permit fluvial erosion to cut the canyons to marine base level, while a subsequent relative sea level rise of the same order of magnitude is required to account for onlap-fill by shallow marine sediments.

Whichever of these models proves correct, a 
noteworthy increase in rate of fall of eustatic sea level, a decrease in rate of tectonic subsidence, or localized tectonic uplift, is required to initiate canyon erosion. If eustatic changes are involved, a signal of this type should leave its record in other Late Proterozoic basins. If such evidence can be found elsewhere at the equivalent sequence boundary, then the case for a eustatic control may be strong. Absence of such evidence may argue for more local base level control, perhaps related to tectonic uplift during sedimentation. The problem in this case is the large amount of uplift required, which would be in excess of $1 \mathrm{~km}$. Uplifts of this magnitude are possible in tectonic settings such as the Colorado Plateau, but such a situation is not obviously compatible with the observed tectonic setting of the Adelaide Geosyncline during Wilpena Group deposition. Research is continuing on sequences and sequence boundaries of the Wilpena Group and its stratigraphic equivalents in other basins, in order to clarify some of these enigmatic observations.

\section{ACKNOWLEDGMENTS}

Fruitful discussions and field studies with Adelaide Geosyncline coworkers Ian Dyson, Karl Eickhoff, Pete DiBona, Jonathan Clarke, Ukat Sukanta, Steve Abbott and Chris Hill are gratefully acknowledged. Esso Australia Ltd, the Australian Research Grants Scheme and the Flinders University Research Budget supported fieldwork by von der Borch and Grady. Travel to Australia by Christie-Blick was supported in part by the Donors of the Petroleum Research Fund, administered by the American Chemical Society (PRF 16042-G2 to N.C.B.) and by LamontDoherty Geological Observatory. Typing was done by Inara Stuart and drafting by Gail Jackson. We thank David McCormick and Charlotte Schreiber for their helpful reviews. We are also indebted to Vic Gostin, Larry Frakes, Barry Webby and an anonymous reviewer for their critical comments. We also appreciated critical comments in the field from members of I.A.S. excursion No. 27b (1986). LamontDoherty Geological Observatory Reference No. 4209 (Christie-Blick).

\section{REFERENCES}

Baker P. A. \& Burns S. J. 1985. Occurrence and formation of dolomite in organic-rich continental margin sediments. American Association of Petroleum Geologists Bulletin 69, 1917-1930.

BJoRLYKKe K. 1982. Correlation of late Precambrian and early Palaeozoic sequences by eustatic sealevel changes and the selection of the PrecambrianCambrian boundary. Precambrian Research 17, 99-104.

CAMprell C. V. 1967. Lamina, laminaset, bed and bedset. Sedimentology 8, 7-26.

Christie-Blick N. \& Levy M. 1985. A new approach to time correlation in Proterozoic rocks: sequence boundaries in the Brigham Group, Utah. Geological Society of America, Abstracts with Programs 17, 546.

Christie-Blick N. \& von der BorCh C. C. 1985. Sequence boundaries in Proterozoic successions: a comparison of the Brigham Group (Utah) and Wilpena Group (South Australia), with implications for sea-level change and global correlation. Geological Society of America, Abstracts with Programs 17, 546.

ContS R. P. 1973. Copley. 1:250,000 Geological Sheet. Geological Survey of South Australia, Explanatory Notes 1:250000 Geological Series SH/54-9.

COATS R. P. \& Preiss W. V. 1980. Stratigraphic and geochronological reinterpretation of late Proterozoic glaciogenic sequences in the Kimberley region, Western Australia. Precambrian Research 13, 181-208.

DI BoNA P. A. \& von DER BorCH C. C. 1985. Wonoka Formation sedimentation, relative sealevel, and basin analysis in the northern Flinders Ranges, South Australia. Geological Society of Australia, Abstracts 15, 228.

DOTT R. H. JR. 1983. 1982 SEPM Presidential address: Episodic sedimentation - How normal is average? How rare is rare? Does it matter? Journal of Sedimentary Petrology 53, 5-23.

Eickhoff K. H., vON DER BORCH C. C. \& GRady A. E. 1986. Incised meandering canyon in the late Proterozoic Wilpena Group; problems of timing and thalweg migration. International Sedimentological Congress, Canberra, Abstracts 92.

Gehling J. G. 1983. The Ediacara Member: a shallowing upward submarine fan sequence within the Pound Subgroup. Geological Society of Australia, Abstracts 10, 52-54.

Gostin V. A. \& JeNKINS R. F. 1983. Sedimentation of the early Ediacaran, Flinders Ranges, South Australia. Geological Society of Australia, Abstracts 9, 196-197.

Grotzinger J. P. 1986. Cyclicity and paleoenvironmental dynamics, Rocknest Platform, northwest Canada. Geological Society of America Bulletin 97 , 1208-1231. 
Haines P. W. 1986a. The upper Wilpena Group at Bunyeroo Gorge, a one day excursion. In Dalgarno C. R. compiler. Proterozoic to Cambrian sedimentary environments and resource potential, Flinders Ranges, South Australia. Guidebook, Eighth Australian Geological Convention, Geological Society of Australia.

HaINES P. W. 1986b. Late Proterozoic carbonate shelf to shale basin transition, Wonoka Formation, Flinders Ranges, S.A. Geological Society of Australia, Abstracts 15, 92.

Jenkins R. F., Ford C. H. \& Gehling J. G. 1983. The Ediacara Member of the Rawnsley Quartzite: the context of the Ediacaran assemblage (late Precambrian, Flinders Ranges). Journal of the Geological Society of Australia 30, 101-119.

JENKINS R. F. \& Gostin V. A. 1983. Marinoan and Ediacaran type sections in the context of tectonic cycles in the Adelaide Geosyncline. Geological Society of Australia, Abstracts 10, 39-44.

Mitchum R. M. JR, Vail P. R. \& Thompson S. III 1977. Seismic stratigraphy and global changes of sealevel, Part 2: the depositional sequence as a basic unit for stratigraphic analysis. American Association of Petroleum Geologists Memoir 26, 53-62.

MUTTI E. 1985. Turbidite systems and their relations to depositional sequences. In Zuffa G.G. ed. Provenance of arenites, pp. 65-93. D. Reidel Publishing Co., Boston.

Pipiringos G. N. \& O'Sullivan R. B. 1978. Principal unconformities in Triassic and Jurassic rocks, western interior United States - a preliminary survey. United States Geological Survey Professional Paper 1035-A.

Plummer P. S. 1978a. Stratigraphy of the lower Wilpena Group (late Precambrian, Flinders Ranges, South Australia). Transactions of the Royal Society of South Australia 102, 25-38.

Plummer P. S. 1978b. Note on the palaeoenvironmental significance of the Nuccaleena Formation (upper Precambrian), Central Flinders Ranges, South Australia. Journal of the Geological Society of Australia 25, 395-402.

Prave A. R. 1985. Can hummocky cross-stratification be formed below effective wave base? Geological Society of America, Abstracts with Programs 117, 693.

Preiss W. V. 1983. Adelaide Geosyncline and Stuart Shelf: Precambrian and Palaeozoic geology. 1:600,000 scale geological map, Department of Mines \& Energy, Adelaide.

Preiss W. V. \& Forbes B. G. 1981. Stratigraphy, correlation and sedimentary history of Adelaidean (late Proterozoic) basins in Australia. Precambrian Research 15, 155-304.

Preiss W. V., Walter M. R., Coats R.- P. \& WeLLS A. T. 1978. Lithological correlations of
Adelaidean glaciogenic rocks in parts of the Amadeus, Ngalia and Georgina Basins. BMR Journal of Australian Geology \& Geophysics 3, 43-53.

Rutland R. W. R., Parker A. J., Pitt G. M., Preiss W. V. \& MurRell, B. 1981. The Precambrian of South Australia. In Hunter D. R. ed. Precambrian of the Southern Hemisphere. Developments in Precambrian Geology 2, 309-360. Elsevier, Netherlands.

SLoss L. L. 1963. Sequence in the cratonic interior of North America. Geological Society of America Bulletin 74, 93-113.

Thompson B. P., Mirams R. C., Forbes B. G., Dalgarno C. R. \& Johnson J. E. 1964. Precambrian rock groups in the Adelaide Geosyncline: a new subdivision. Quarterly Geological Notes, Geological Survey of South Australia 9 , $1-10$.

Vail P. R., Hardenbol J. \& Todn R. G. 1984. Jurassic unconformities, chronostratigraphy, and sea-level changes from seismic stratigraphy and biostratigraphy. In Schlee J.S. ed. Interregional unconformities and hydrocarbon accumulation. American Association of Petroleum Geologists Memoir 36, 129-144.

Vail P. R., Mitchum R. M. JR \& Thompson S. III 1977. Seismic stratigraphy and global changes of sealevel, Part 3: Relative changes of sealevel from coastal onlap. American Association of Petroleum Geologists Memoir 26, 63-81.

VON DER BORCH C. C. 1969. Submarine canyons of southeastern New Guinea: seismic and bathymetric evidence for their modes of origin. Deep Sea Research 16, 323-328.

VON DER BORCH C. C. 1980. Evolution of late Proterozoic to early Paleozoic Adelaide Foldbelt, Australia: comparisons with post-Permian rifts and passive margins. Tectonophysics 70, 115-134.

von der Borch C. C., Grady A. E., Aldam R., et al 1985. A large-scale meandering submarine canyon: outcrop example from the late Proterozoic Adelaide Geosyncline, South Australia. Sedimentology 32, 507-518.

VON DER BORCH C. C. \& LOCK D. 1979. Geological significance of Coorong dolomites. Sedimentology 26, 813-824.

voN DER Borch C. C., SMIT R. \& Grady A. E. 1982. Late Proterozoic submarine canyons of Adelaide Geosyncline, South Australia. American Association of Petroleum Geologists Bulletin 66, 332-347.

WALKER R. G. 1984. Shelf and shallow marine sands. In Walker R. G. ed. Facies Models, second edition, pp. 141-170. Geoscience Canada Reprint Series 1.

Williams G. E. 1979. Sedimentology, stable-isotope 
geochemistry and palaeoenvironment of dolostones capping late Precambrian glacial sequences in Australia. Journal of the Geological Society of Australia 26, 337-386.

Young G. M. 1981. The Amundsen Embayment, Northwest Territories: relevance to the upper
Proterozoic evolution of north America. In Campbell F. H. A. ed. Proterozoic basins of Canada. Geological Survev of Canada Paper 81-10.

(Received 16 February 1987; accepted 12 June 1987) 